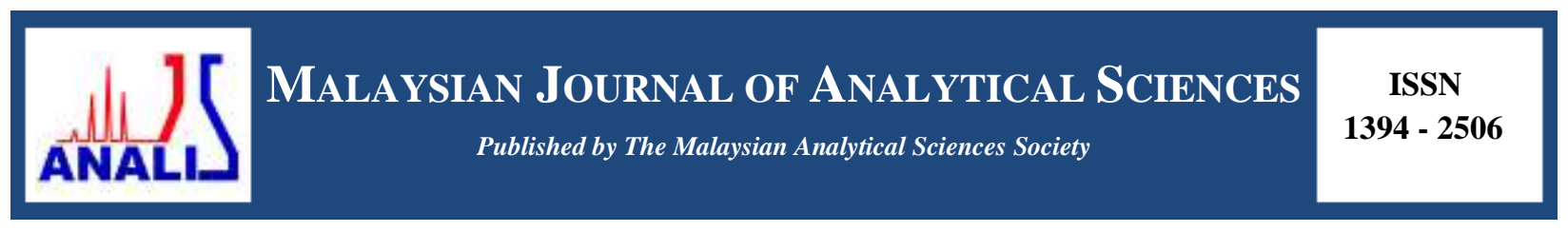

\title{
BREAKDOWN OF HYDROGEN SULFIDE IN SEAWATER UNDER DIFFERENT RATIO OF DISSOLVED OXYGEN / HYDROGEN SULFIDE
}

\author{
(Penguraian Hidrogen Sulfida dalam Air Laut dengan Nisbah Oksigen Terlarut / Hidrogen \\ Sulfida yang Berbeza)
}

\author{
Hii Yii Siang ${ }^{1}$, Norhayati Mohd Tahir ${ }^{2}$, Abdul Malek $^{3}$, Mohd Azlan Md Isa $^{3}$ \\ ${ }^{1}$ School of Fisheries and Aquaculture Science \\ ${ }^{2}$ School of Marine and Environmental Sciences \\ University Malaysia Terengganu, 21030 Kuala Nerus, Terengganu, Malaysia \\ ${ }^{3}$ Sapura Kencana Energy Inc., Level 6, Menara Sapura Kencana Petroleum, Solaris Dutamas, \\ Jalan Dutamas 1, 50480 Kuala Lumpur, Malaysia \\ *Corresponding author: hii@umt.edu.my
}

Received: 29 November 2016; Accepted: 8 August 2017

\begin{abstract}
Breakdown of hydrogen sulfide $\left(\mathrm{H}_{2} \mathrm{~S}\right)$ in seawater is highly dependent on both the concentration of dissolved $\mathrm{H}_{2} \mathrm{~S}$ and dissolved oxygen (DO). A simple correlation was found in the $\mathrm{H}_{2} \mathrm{~S}$ dissociation and ratio of $\left[\mathrm{DO} / \mathrm{H}_{2} \mathrm{~S}\right]$. When the $\left[\mathrm{DO} / \mathrm{H}_{2} \mathrm{~S}\right] \mathrm{ratio}$ is more than one, $\mathrm{H}_{2} \mathrm{~S}$ breakdown rapidly, resulting in a short half-life of $\mathrm{H}_{2} \mathrm{~S}$ in the seawater (in a time scale of minute). When the dissolved oxygen is not a limiting factor, $\mathrm{H}_{2} \mathrm{~S}$ breakdown in a first order reaction. Nevertheless, when $\left[\mathrm{DO} / \mathrm{H}_{2} \mathrm{~S}\right] \mathrm{ratio}$ is less than $1, \mathrm{H}_{2} \mathrm{~S}$ breakdown in the seawater becomes slower, resulting in a longer $\mathrm{H}_{2} \mathrm{~S}$ half-life (in a time scale up to hours). In this case, the $\mathrm{H}_{2} \mathrm{~S}$ breakdown in a pseudo-second order reaction. This pseudo-second order reaction is commonly reported by other investigators. This study also investigated the relation between the concentration of dissolved $\mathrm{H}_{2} \mathrm{~S}$ and $\mathrm{pH}$ changes during $\mathrm{H}_{2} \mathrm{~S}$ dissociation in the seawater. The $\mathrm{pH}$ is lowered with increasing concentration of initial $\mathrm{H}_{2} \mathrm{~S}$ in the seawater but appears to reach an asymptotic low value of about 4 as the dissolved $\mathrm{H}_{2} \mathrm{~S}$ approaches its saturation limit in the seawater at about 2,500 $\mathrm{mg} \mathrm{L}^{-1}$.
\end{abstract}

Keywords: hydrogen sulfide, dissolved oxygen, oxidation, seawater, $\mathrm{H}_{2} \mathrm{~S}$ dissociation

\section{Abstrak}

Penguraian hidrogen sulfida $\left(\mathrm{H}_{2} \mathrm{~S}\right)$ dalam air laut sangat bergantung kepada kepekatan kedua-dua $\mathrm{H}_{2} \mathrm{~S}$ terlarut dan oksigen terlarut (DO). Satu kolerasi mudah telah ditemui antara penguraian $\mathrm{H}_{2} \mathrm{~S}$ dan nisbah $\left[\mathrm{DO} / \mathrm{H}_{2} \mathrm{~S}\right.$. Apabila nisbah [DO/ $\left.\mathrm{H}_{2} \mathrm{~S}\right]$ melebihi satu, penguraian $\mathrm{H}_{2} \mathrm{~S}$ adalah cepat, menyebabkan separuh hayat $\mathrm{H}_{2} \mathrm{~S}$ yang pendek dalam air laut (dalam skala masa minit). Dalam keadaan yang mana oksigen terlarut bukan faktor penghad, penguraian $\mathrm{H}_{2} \mathrm{~S}$ merupakan tindak balas tertib pertama. Namun, apabila nisbah $\left[\mathrm{DO} / \mathrm{H}_{2} \mathrm{~S}\right]$ kurang daripada satu, penguraian $\mathrm{H}_{2} \mathrm{~S}$ dalam air laut menjadi lambat, menyebabkan separuh hayat $\mathrm{H}_{2} \mathrm{~S}$ yang lebih lama (dalam skala masa jam). Dalam kes ini, penguraian $\mathrm{H}_{2} \mathrm{~S}$ adalah tindak balas pseudo tertib kedua. Tindak balas pseudo tertib kedua ini biasa dilaporkan oleh ramai penyelidik. Kajian ini turut menyiasat hubung kait antara kepekatan $\mathrm{H}_{2} \mathrm{~S}$ terlarut dan perubahan $\mathrm{pH}$ semasa penguraian $\mathrm{H}_{2} \mathrm{~S}$ dalam air laut. Nilai $\mathrm{pH}$ jadi rendah dengan peningkatan kepekatan awal $\mathrm{H}_{2} \mathrm{~S}$ dalam air laut tapi ia mencapai nilai asimptot yang rendah dalam lingkungan 4 apabila kepekatan $\mathrm{H}_{2} \mathrm{~S}$ terlarut menghampiri had ketepuannya dalam air laut pada kepekatan 2,500 $\mathrm{mg} \mathrm{L}^{-1}$.

Kata kunci: hidrogen sulfida, oksigen terlarut, pengoksidaan, air laut, penguraian $\mathrm{H}_{2} \mathrm{~S}$ 


\section{Introduction}

Hydrogen Sulfide $\left(\mathrm{H}_{2} \mathrm{~S}\right)$ gas is one of the potential contaminant found in oil and gas production. $\mathrm{H}_{2} \mathrm{~S}$ is normally formed in oil and/or gas reservoirs through the decomposition of organic matter under anaerobic condition by microbes. Typically, such $\mathrm{H}_{2} \mathrm{~S}$ will be removed from the main hydrocarbon stream and disposed off to increase the sales value of the sweetened hydrocarbon. In the ocean, $\mathrm{H}_{2} \mathrm{~S}$ is mainly formed through geochemical processes during deep sea volcanic activities including hydrothermal vents [1]. When $\mathrm{H}_{2} \mathrm{~S}$ is present in the seawater in dissolved form, it dissociates into hydrosulfide ( $\left.\mathrm{HS}^{-}\right)$, which is the product of the first dissociation equilibrium $\left(\mathrm{K}_{\mathrm{a} 1}\right)$. The second dissociation equilibrium $\left(\mathrm{K}_{\mathrm{a} 2}\right)$ produces the sulfide ion $\left(\mathrm{S}^{2-}\right) . \mathrm{H}_{2} \mathrm{~S}$ is a weak acid, with $\mathrm{pK}_{\mathrm{a} 1}$ being reported by various investigators in the order of 7.0 [2-5] and $\mathrm{pK}_{\mathrm{a} 2}$ in the order of 12.5 [6]. Due to the first dissociation of $\mathrm{H}_{2} \mathrm{~S}$ to $\mathrm{HS}^{-}$, the concentration of aqueous $\mathrm{H}_{2} \mathrm{~S}$ will decrease with increasing $\mathrm{pH}$ in water. At $\mathrm{pH}$ 7.0, the concentration ratio of the aqueous $\mathrm{H}_{2} \mathrm{~S}$ to $\mathrm{HS}^{-}$is approximately 1:1. As the $\mathrm{pH}$ increases beyond 7.0, the ratio of the concentration of $\mathrm{HS}^{-}$to aqueous $\mathrm{H}_{2} \mathrm{~S}$ increases. Sulfide ion $\left(\mathrm{S}^{2-}\right)$, which is the product of the second dissociation becomes significant, only when $\mathrm{pH}$ is above 12 .

The hydrosulfide ion is susceptible to oxygenation reactions under aerobic condition in seawater. The oxygenation of $\mathrm{HS}^{-}$is rather complex, involving a multitude of chemical reactions, producing various intermediate and final products, amongst others, the following possible reactions $1-3[7,8]$ :

$$
\begin{aligned}
& 2 \mathrm{HS}^{-}+3 \mathrm{O}_{2} \rightarrow 2 \mathrm{SO}_{3}{ }^{2-}+2 \mathrm{H}^{+} \\
& \mathrm{HS}^{-}+2 \mathrm{O}_{2} \rightarrow \mathrm{SO}_{4}{ }^{2-}+\mathrm{H}^{+} \\
& 2 \mathrm{HS}^{-}+2 \mathrm{O}_{2} \rightarrow \mathrm{S}_{2} \mathrm{O}_{3}{ }^{2-}+\mathrm{H}_{2} \mathrm{O}
\end{aligned}
$$

In the presence of relatively high concentration of dissolved oxygen (DO), the ion species of sulfite $\left(\mathrm{SO}_{3}{ }^{2-}\right)$ is stable. Even so, some of the $\mathrm{SO}_{3}{ }^{2-}$ species would also be oxidized to sulfates $\left(\mathrm{SO}_{4}{ }^{2-}\right)$ [7, 9]. Hence, it is apparent that the actual overall oxidation rate of $\mathrm{H}_{2} \mathrm{~S}$ in seawater varies depending on the conditions studied. A simplified gross measure of the overall breakdown of $\mathrm{H}_{2} \mathrm{~S}$ in seawater due to various reactions shown above can be depicted by the $\mathrm{H}_{2} \mathrm{~S}$ half-life; which is a measure of the time taken to lower the $\mathrm{H}_{2} \mathrm{~S}$ concentration from its initial value to half the initial value. Various publications have provided different $\mathrm{H}_{2} \mathrm{~S}$ half-life values, depending on the reaction conditions investigated. Göte and Alexander [10] reported that the $\mathrm{H}_{2} \mathrm{~S}$ half-life of about 17 minutes at constant dissolved oxygen concentration of $5.4 \mathrm{mg} \mathrm{L}^{-1}$ and $25{ }^{\circ} \mathrm{C}$ in seawater. Sharma and Yuan [11] reported $\mathrm{H}_{2} \mathrm{~S}$ half-life of 25 minutes for treated domestic wastewater initially containing about $6 \mathrm{mg} \mathrm{L}^{-1}$ of $\mathrm{H}_{2} \mathrm{~S}$ and $8 \mathrm{mg} \mathrm{L}^{-1} \mathrm{DO}$, while Asaoka et al. [12] reported an in-situ half-life of approximately 50 minutes in the Etajima Bay, which contains about $28 \mathrm{mg}$ $\mathrm{L}^{-1}$ of sulfide.

Decomposition of the $\mathrm{H}_{2} \mathrm{~S}$ becomes more complicated when microbial degradation is also taking place [13] or when catalytic metals are present [14]. Oxidized metals such as Fe(III), $\mathrm{Mn}(\mathrm{III})$ and $\mathrm{Mn}(\mathrm{IV})$, for example, are efficient catalysts to overcome the kinetic barrier for the chemical oxidation of sulfides [15]. The interaction of all these factors in the seawater leads to unpredictable outputs in the tropical marine environment. It is apparent that the halflife of $\mathrm{H}_{2} \mathrm{~S}$ dissociation in such waters is quite complex and dependent on the physical chemical properties as well as biological assemblage of the seawater. Thus, whenever the rate of $\mathrm{H}_{2} \mathrm{~S}$ decomposition is the intended subject, invariably there is a need to conduct in-situ verification using the actual seawater source. Understanding the rate of $\mathrm{H}_{2} \mathrm{~S}$ breakdown in seawater is important in environmental management as it plays an important role in toxicity and ecological footprint of the toxic gas in the marine environment. Hence, this paper describes the experiments undertaken to determine the rate of $\mathrm{H}_{2} \mathrm{~S}$ breakdown in seawater obtained from the Terengganu offshore, as representative of the offshore water of Peninsular Malaysia. The study includes analysis to derive appropriate rate equations and rate constant(s) for the $\mathrm{H}_{2} \mathrm{~S}$ breakdown in seawater as well as estimations of the dissociation half-life. In addition, the effect of $\mathrm{H}_{2} \mathrm{~S}$ dissociation on the $\mathrm{pH}$ of the resultant solution is of particular interest. In freshwater, the dissolution of $\mathrm{H}_{2} \mathrm{~S}$ into $\mathrm{HS}^{-}$ions generate protons, which effectively lowers the $\mathrm{pH}$ of the solution. However, in seawater, the natural alkalinity of the seawater tends to counteract the lowering of the $\mathrm{pH}$ through various carbonaceous compounds in the seawater carbonate equilibrium. This can result in a complex, non-linear $\mathrm{pH}$ correlation with concentration of $\mathrm{H}_{2} \mathrm{~S}$ dissolution. In this study, it is desired to establish an empirical relationship between the effect of $\mathrm{H}_{2} \mathrm{~S}$ dissolution and resultant $\mathrm{pH}$ of the seawater solution. 


\section{Materials}

\section{Materials and Methods}

Seawater used in this experiment was collected from the South China Sea off Terengganu. The seawater was then filtered and acclimatized for one week before use. $1 \mathrm{~L}$ Kipps apparatus was used to produce the hydrogen sulfide $\left(\mathrm{H}_{2} \mathrm{~S}\right)$ gas used in this study. In the Kipps apparatus, excess pyrite $\left(\mathrm{Fe}_{2} \mathrm{~S}\right)$ was allowed to react with hydrochloric acid (20\%) to generate $\mathrm{H}_{2} \mathrm{~S}$ gas. The gas was bubbled into $1 \mathrm{~L}$ oxygen-free deionized water for 24 hours to produce an approximately $2000 \mathrm{mg} \mathrm{L}^{-1} \mathrm{H}_{2} \mathrm{~S}$ aliquot for the subsequent experiments. Oxygen free water was prepared by purging deionized water with pure nitrogen at $30 \mathrm{~mL} \mathrm{~s}^{-1}$ for 40 minutes. High Purity oxygen and nitrogen (> $99 \%$ ) gases were used in this study. All the chemicals used in the study were of analytical grade and supplied by Merck Co.

\section{Determination of hydrogen sulfide in seawater}

Hydrogen sulfide $\left(\mathrm{H}_{2} \mathrm{~S}\right.$ ) probe (MS-AQUA) was used to monitor $\mathrm{H}_{2} \mathrm{~S}$ concentration in the experiments. Analysentechnik $\mathrm{GmbH}$ develops the amperometric MS-AQUA $\mathrm{H}_{2} \mathrm{~S}$ micro sensor for in-situ determination of dissolved $\mathrm{H}_{2} \mathrm{~S}$ or Total sulfide in aqueous solution within a $\mathrm{pH}$ range of 0 to 8. Other than the ion sensitive electrode (ISE), the MS-AQUA is the only method for in-situ $\left[\mathrm{H}_{2} \mathrm{~S} /\right.$ Total Sulfide] measurement. MS-AQUA is more relevant as compared to the other ISEs because the workable $\mathrm{pH}$ range of MS-AQUA is more relevant to the study undertaken. The accuracy and the concentration of the MS-AQUA below $3 \mathrm{mg} \mathrm{L}^{-1}$ is essentially better than the other ISEs. Table 1 shows the technical data extracted from the technical manual of the sensor. $\mathrm{The}_{2} \mathrm{H}_{2} \mathrm{~S}$ probe was pre-calibrated by the manufacturer and was validated with standard solutions by comparing the concentration obtained from the probe and the standard methods (APHA 4500-S ${ }^{2-} \mathrm{F}$., Iodometric method and APHA 4500-S ${ }^{2-} \mathrm{H}$, calculation of unionized $\mathrm{H}_{2} \mathrm{~S}$ ) [16]. Dissolved oxygen and $\mathrm{pH}$ were determined by using YSI 550a and the pH probe of the MS-AQUA respectively.

Table 1. Technical specification of MS-AQUA $\mathrm{H}_{2} \mathrm{~S}$ probes used in the study

\begin{tabular}{|c|c|}
\hline Technical Specification & Range \\
\hline $\begin{array}{l}\text { Measurement range } \\
\text { - Type I* } \\
\text { - Type II } \\
\text { - Type III* } \\
\text { Accuracy of the sensor } \\
\text { Temperature range } \\
\text { pH range } \\
\text { Salinity range } \\
\text { Signal Interference } \\
\text { - Carbon dioxide } \\
\text { - Methane } \\
\text { - Hydrogen } \\
\text { - Ammonia } \\
\text { - Carbon monoxide } \\
\text { - Carbon disulfide } \\
\text { - Acetic acid } \\
\text { - Dimethyl sulfide } \\
\text { - Ethanol }\end{array}$ & $\begin{array}{l}\text { - } \quad 10 \mu \mathrm{g} \mathrm{L}^{-1}-3 \mathrm{mg} \mathrm{L}^{-1} \mathrm{H}_{2} \mathrm{~S} \\
-\quad 50 \mu \mathrm{g} \mathrm{L}^{-1}-10 \mathrm{mg} \mathrm{L}^{-1} \mathrm{H}_{2} \mathrm{~S} \\
\quad 500 \mu \mathrm{g} \mathrm{L}^{-1}-50 \mathrm{mg} \mathrm{L}^{-1} \mathrm{H}_{2} \mathrm{~S} \\
2 \% \\
0^{\circ} \mathrm{C}-30^{\circ} \mathrm{C} \\
0-8 \\
<40 \mathrm{ppt}\left(\mathrm{g} \mathrm{L}^{-1}\right) \\
\text { Up to } 25.38 \% \\
\text { Up to } 5.78 \% \\
\text { Up to } 0.544 \% \\
\text { Up to } 1000 \mathrm{ppm} \\
\text { Up to } 92 \mathrm{ppm} \\
\text { Up to } 5 \% \\
\text { Up to } 1 \mathrm{~mol} \mathrm{~L} \\
\text { Up to } 10 \% \\
\text { Up to } 10 \%\end{array}$ \\
\hline
\end{tabular}

* Sensors used in this study

APHA Method 4500-S $\mathrm{S}^{2}-\mathrm{F}$ [16] was also used to validate the reading from the probe as well as to determine those concentration that fell beyond the measurement range of the MS-AQUA. In the case where the $\mathrm{H}_{2} \mathrm{~S}$ level exceeded the measurement range, water sample was collected from the experimental chamber by using syringe acted as a 
piston to drive water sample out of the vessel. Samples drawn out from the experiment was analyzed for its $\mathrm{pH}$ and $\mathrm{H}_{2} \mathrm{~S}$ level right after sampling. Briefly, $20 \mathrm{~mL}$ of iodine solution $(0.025 \mathrm{~N})$ followed by $2 \mathrm{~mL} 6 \mathrm{~N} \mathrm{HCl}$ was poured into a $500 \mathrm{~mL}$ flask. An amount $200 \mathrm{~mL}$ sample was discharged under the solution surface into the flask. More iodine solution was added if the color of the iodine disappeared. The sample was then back-titrated with standard sodium thiosulfate solution $(0.025 \mathrm{~N})$. A few drops of starch solution were added as indicator for the end point (disappearance of blue color). The concentration of total sulfide was then calculated, taking into account the dilution factor during titration. The concentration of unionized $\mathrm{H}_{2} \mathrm{~S}$ is then calculated by multiplying the dissociation factor at the measured $\mathrm{pH}$ with the total sulfides as stipulated in APHA Method $4500-\mathrm{S}^{2}-\mathrm{H}$ [16].

\section{Breakdown of hydrogen sulfide in seawater}

Experimental chamber as shown in Figure 1 was used in this study. The chamber consists four major components; 1. $\mathrm{H}_{2} \mathrm{~S}$, temperature and $\mathrm{pH}$ probes, 2. Aliquot injection port, 3. Dissolved oxygen probes, and 4. Magnetic bar and stirrer. The experimental chamber was incubated in a $20 \mathrm{~L}$ water bath. The reactor vessel was first filled with $2 \mathrm{~L}$ of seawater. Pure oxygen and nitrogen from gas cylinders were used to adjust the level of dissolved oxygen in the seawater. $50 \mathrm{~mL}$ syringe was used to inject concentrated $\mathrm{H}_{2} \mathrm{~S}$ aliquot through the injection port into the reactor. The volume of concentrated $\mathrm{H}_{2} \mathrm{~S}$ solution injected into the reactor was obtained based on dilution equation $\left(\mathrm{M}_{1} \mathrm{~V}_{1}=\right.$ $\mathrm{M}_{2} \mathrm{~V}_{2}$ ) to make up the desired $\mathrm{H}_{2} \mathrm{~S}$ concentration. The volume of injection was limited to less than $2 \%$ of the total reactor volume. No head space was permitted in the chamber throughout the experiment. In order to avoid leakages, all ports were sealed with silicon glue. Magnetic bar and stirrer $(300 \mathrm{rpm})$ were used to homogenize the aliquot and seawater in the experimental vessel. The experiments were conducted in the laboratory at $28^{\circ} \mathrm{C}, \mathrm{pH} 8.0$ and $30 \mathrm{ppt}$. Experiment started one minute after injection of the $\mathrm{H}_{2} \mathrm{~S}$ aliquot. This is to ensure sample homogeneity in the vessel. Readings were recorded continuously by using a camcorder and then manually transferred into excel spreadsheet. The data were then used to determine the reaction order, rate and constant. All the experiments were conducted in triplicate.

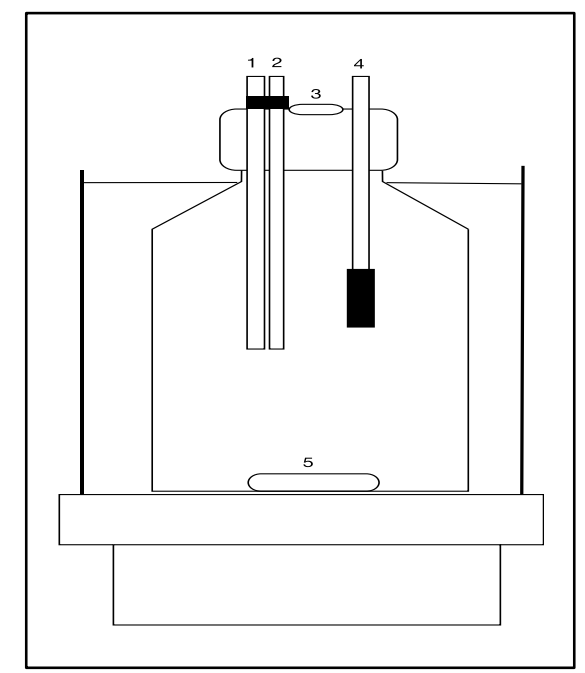

Figure 1. Experimental setup for investigation of $\mathrm{H}_{2} \mathrm{~S}$ removal in seawater. $1 . \mathrm{H}_{2} \mathrm{~S}$, temperature and pH probes, 2. Aliquot injection port, 3. Dissolved oxygen probe, 4. Magnetic bar and stirrer

\section{$\mathrm{H}_{2} \mathrm{~S}$ solubility and $\mathrm{pH}$ changes in seawater}

Prior to the main $\mathrm{H}_{2} \mathrm{~S}$ breakdown rate experiments, solubility of the $\mathrm{H}_{2} \mathrm{~S}$ in seawater was tested using the experimental setup as shown in Figure 2. In the experiment, $\mathrm{H}_{2} \mathrm{~S}$ gas generated from Kipps apparatus was bubbled through the seawater at $28^{\circ} \mathrm{C}, 30 \mathrm{ppt}$ and $\mathrm{pH} 8.0$ in a $2 \mathrm{~L}$ vessel through port 2 . Port 4 is the vent for excess gas. During sample withdrawal, port 4 was clipped and the syringe (5) was used as a piston to drive water sample out of the vessel through port 3 . The concentration of the $\mathrm{H}_{2} \mathrm{~S}$, temperature, $\mathrm{pH}$ and dissolved oxygen were determined 
immediately. The experiments were conducted in a $20 \mathrm{~L}$ water bath for consistent temperature at $28{ }^{\circ} \mathrm{C}\left( \pm 0.5^{\circ} \mathrm{C}\right)$. All the experiments were conducted in three replicates.

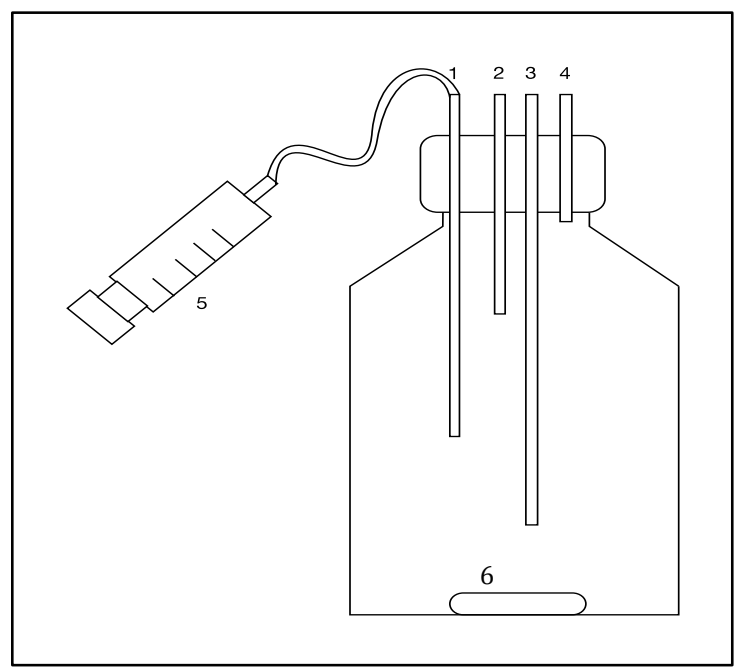

Figure 2. Experimental setup for investigating hydrogen sulfide solubility. 1. Piston inlet for sampling, 2. Gas inlet from Kipps apparatus, 3. Sample outlet, 4. Excess gas exhaust, 5. Syringe, 6. Magnetic bar

\section{Determination of reaction order, rate constant and half-life}

Data obtained from $\mathrm{H}_{2} \mathrm{~S}$ breakdown experiments were used to determine the reaction order, rate constant and halflife of the $\mathrm{H}_{2} \mathrm{~S}$ removal. Reaction kinetics were studied based on computation procedure of Han et al. [17]. The reaction orders, rate constants and half-life were obtained by using graphical method. In the case where the dissolved oxygen is in excess, the reaction constant and the breakdown rate of the $\mathrm{H}_{2} \mathrm{~S}$ would resemble the pseudofirst order $\left(\mathrm{K}_{1}\right)$ reaction as $(4)$ :

$$
\frac{d\left[\mathrm{H}_{2} S\right]}{d t}=-K_{1}\left[H_{2} S\right]_{t}
$$

Where, $\left[\mathrm{H}_{2} \mathrm{~S}\right]_{\mathrm{t}}$ is define as concentration of hydrogen sulfide at time $\mathrm{t}$ and $\mathrm{K}_{1}$ is define as rate constant.

While, the reaction constant and the breakdown rate of the $\mathrm{H}_{2} \mathrm{~S}$ resemble a second order reaction, it represented as (5):

$$
\frac{d\left[H_{2} S\right]}{d t}=-K_{2}\left[H_{2} S\right]_{t}\left[O_{2}\right]_{t}
$$

where, $\left[\mathrm{H}_{2} \mathrm{~S}\right]_{\mathrm{t}}$ is define as concentration of hydrogen sulfide at time $\mathrm{t},\left[\mathrm{O}_{2}\right]_{\mathrm{t}}$ is define as concentration of dissolved oxygen at time $t$ and $\mathrm{K}_{2}$ is rate constant.

The reaction constant for second order reaction, $\mathrm{K}_{2}$, can be assessed by dividing $\mathrm{K}_{1}$ with $\left[\mathrm{O}_{2}\right]_{\mathrm{t}} . \mathrm{K}_{1}$ can also be derived from the concentration graphs by computing the gradient of the $\mathrm{H}_{2} \mathrm{~S}$ concentration over the linear portion of the decline and dividing by the average concentration of $\mathrm{H}_{2} \mathrm{~S}$ over the considered range. Comparing equations (4) and (5), $\mathrm{K}_{2}$ can be estimated from $\mathrm{K}_{1} /\left[\mathrm{O}_{2}\right]$. Since the DO concentration in the seawater for the case of lower DO/ $\mathrm{H}_{2} \mathrm{~S}$ concentration ratio is expected to decline in tandem with the breakdown of $\mathrm{H}_{2} \mathrm{~S}$, estimation of $\mathrm{K}_{2}$ in this case, is applicable only over a narrow time range where the DO concentration within that time range does not resulted in a significant differences in $\mathrm{K}_{2}$ and $\mathrm{K}_{1}$. In this study, such approximations are restricted to the first few minutes of the experiments, where the $\mathrm{H}_{2} \mathrm{~S}$ concentration decline is still linear and the DO has not declined more than $50 \%$ of its 
initial concentration. Integrating equation (5) provides a mathematical estimate of the $\mathrm{H}_{2} \mathrm{~S}$ dissociation half-life for the experiments (equation $6-8$ ):

$$
\begin{aligned}
& \int \frac{\mathrm{d}[\mathrm{H} 2 \mathrm{~S}]}{[\mathrm{H} 2 \mathrm{~S}]} \mathrm{dt}=-1 \int K_{2}\left[\mathrm{O}_{2}\right] \\
& \frac{1}{\left[\mathrm{O}_{2}\right]_{o}-\left[\mathrm{H}_{2} S\right]_{o}} \ln \frac{\left[\mathrm{O}_{2}\right]_{t}\left[\mathrm{H}_{2} S\right]_{o}}{\left[\mathrm{O}_{2}\right]_{o}\left[\mathrm{H}_{2} S\right]_{t}}=K_{2} t
\end{aligned}
$$

When $\left[\mathrm{O}_{2}\right]_{\mathrm{o}}$ is much higher than $\left[\mathrm{H}_{2} \mathrm{~S}\right]_{\mathrm{o}},\left[\mathrm{O}_{2}\right]_{\mathrm{o}} \sim\left[\mathrm{O}_{2}\right]_{\mathrm{t}}$, equation (6) become (7)

$$
\begin{aligned}
& \frac{1}{\left[\mathrm{O}_{2}\right]_{t}} \ln \frac{\left[\mathrm{H}_{2} \mathrm{~S}\right]_{o}}{\left[\mathrm{H}_{2} \mathrm{~S}\right]_{t}}=K_{2} t \\
& {\left[\mathrm{H}_{2} \mathrm{~S}\right]_{t}=\left[\mathrm{H}_{2} \mathrm{~S}\right]_{o} e^{-\left[\mathrm{O}_{2}\right]_{t} K_{2} t}}
\end{aligned}
$$

Half-life can be determined based on equation (7), as $\left[\mathrm{H}_{2} \mathrm{~S}\right]_{\mathrm{t}}=0.5\left[\mathrm{H}_{2} \mathrm{~S}\right]_{\mathrm{o}}$, thus

$$
t_{1 / 2}=\frac{\ln 0.5}{-K_{2}\left[O_{2}\right]_{o}}
$$

\section{Statistical analysis}

Paired t-test was performed to compare if there is significant different in the reading obtained from $\mathrm{H}_{2} \mathrm{~S}$ probe (MSAQUA) and the standard methods [16]. The statistical analysis was performed by using open source software, $\mathrm{R}$ statistics version 3.3.2.

\section{Validation of $\mathrm{H}_{2} \mathrm{~S}$ probe}

\section{Results and Discussion}

Data obtained by using the $\mathrm{H}_{2} \mathrm{~S}$ probe (MS-AQUA) was cross checked with APHA 4500-S $\mathrm{S}^{2} \mathrm{~F}$ standard method. Experiments and analysis on different concentration of $\mathrm{H}_{2} \mathrm{~S}$ standard solution was conducted to validate the corresponding measurement on the sensor. Results obtained from the probe were not significantly different (paired t-test, $\mathrm{p}>0.05)$ from those obtained by using APHA standard method and there is a correlation between the data values. (Pearson, $\mathrm{P}<0.05, \mathrm{R}^{2}=0.9974$ ). Figure 3 shows the correlation of $\mathrm{H}_{2} \mathrm{~S}$ concentration obtained by using probe and the standard method. Validation of the $\mathrm{H}_{2} \mathrm{~S}$ probe is important because the probe is considered new in the market and there are only few reports on its efficiency in measurement. The probe is responsive towards $\mathrm{H}_{2} \mathrm{~S}$ even it exceeded the measurement range recommended by the manufacturer although the last two points in the validation curve (Figure 3) starts showing deviation from the proportionality.

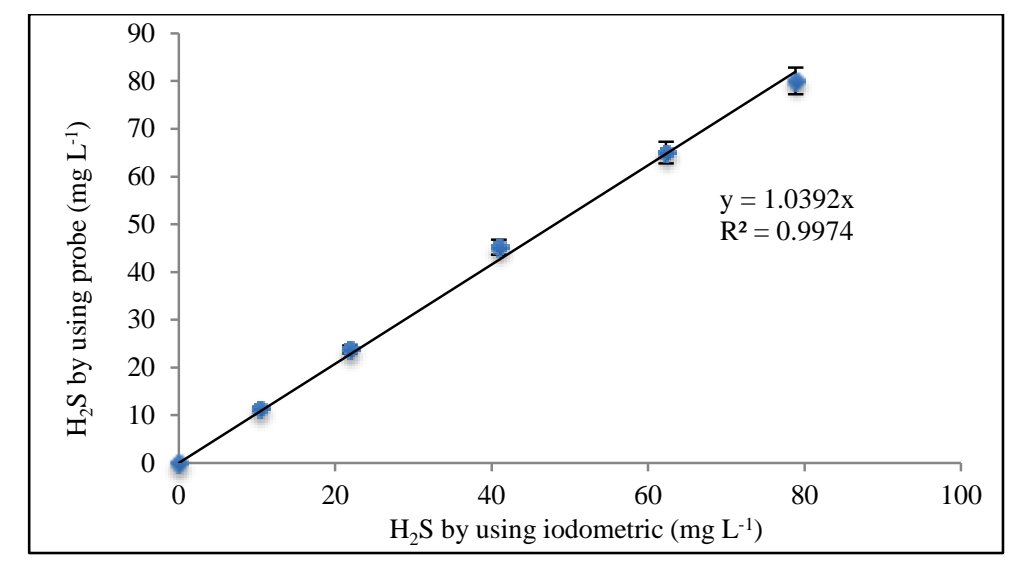

Figure 3. $\mathrm{H}_{2} \mathrm{~S}$ Probe (MS-AQUA) measurement correlated with concentration determined by using APHA standard methods (4500-S ${ }^{2-} \mathrm{F}$ and APHA $\left.4500-\mathrm{S}^{2-} \mathrm{H}\right)$ 


\section{$\mathrm{H}_{2} \mathrm{~S}$ solubility and $\mathrm{pH}$ changes in seawater}

When $\mathrm{H}_{2} \mathrm{~S}$ was continuously bubbled into the seawater, the seawater $\mathrm{pH}$ dropped from an initial value of $\mathrm{pH} 8.01$ down to $\mathrm{pH} 4.27$ as the $\mathrm{H}_{2} \mathrm{~S}$ concentration was approaching $2312 \mathrm{mg} \mathrm{L}^{-1}$ (Figure 4). At $28{ }^{\circ} \mathrm{C}$, the concentration of $\mathrm{H}_{2} \mathrm{~S}$ was saturated at about $2500 \mathrm{mg} \mathrm{L}^{-1}$ in $30 \mathrm{ppt}$ seawater in the experiments. It is anticipated that $\mathrm{H}_{2} \mathrm{~S}$ would equilibrate and evolve into the vapor space at the saturation state. Hence, the $\mathrm{H}_{2} \mathrm{~S}$ concentration used in this study was limited to $1500 \mathrm{mg} \mathrm{L}^{-1}$ to reduce experimental errors and in terms of safety consideration.

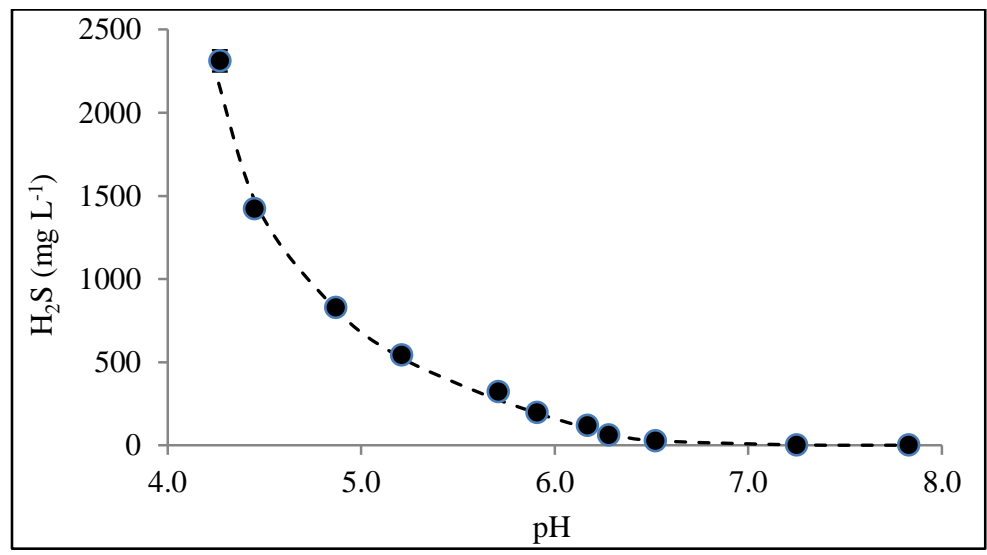

Figure 4. Effect of hydrogen sulfide concentration on seawater $\mathrm{pH}$

\section{Hydrogen sulfide breakdown in seawater at different $[\mathrm{DO}] /\left[\mathrm{H}_{2} \mathrm{~S}\right]$ ratio}

In the presence of excess dissolved oxygen in seawater, dissolved hydrogen sulfide $\left(\mathrm{H}_{2} \mathrm{~S}\right)$ is oxidized rapidly in the seawater. Figure 5 shows the $\mathrm{H}_{2} \mathrm{~S}$ breakdown against time in seawater under aerobic condition. At an initial dissolved oxygen of $10.2 \mathrm{mg} \mathrm{O}_{2} \mathrm{~L}^{-1}$ (Figure 5a), the $\mathrm{H}_{2} \mathrm{~S}$ decomposed from initial $3.2 \mathrm{mg} \mathrm{L}^{-1}$ into half of its initial concentration at $1.6 \mathrm{mg} \mathrm{L}^{-1}$ in about 10 minutes when the ratio of $\left[\mathrm{DO} / \mathrm{H}_{2} \mathrm{~S}\right]$ is 3.4 (Figure $5 \mathrm{a}$ ). The $\mathrm{H}_{2} \mathrm{~S}$ concentration was further decomposed in the seawater. The subsequent half-life of the $\mathrm{H}_{2} \mathrm{~S}$ concentration 1.6 to 0.79 mg L ${ }^{-1}$ was about 9 minute. We repeated the experiment by introduced an initial concentration of $5.2 \mathrm{mgL}^{-1} \mathrm{H}_{2} \mathrm{~S}$ under a $\left[\mathrm{DO} / \mathrm{H}_{2} \mathrm{~S}\right]$ ratio of 3.2 (Figure $5 \mathrm{~b}$ ) at an initial dissolved oxygen of $17.4 \mathrm{mg} \mathrm{O}_{2} \mathrm{~L}^{-1}$, after 10.6 minutes, the $\mathrm{H}_{2} \mathrm{~S}$ concentration dropped to half of its initial concentration. The $\mathrm{H}_{2} \mathrm{~S}$ concentration in this experiment further decomposed to $1.3 \mathrm{mgL}^{-1}$ after 10.4 minutes. In both experiments, the dissolved oxygen remained above $4 \mathrm{mgL}^{-1}$ at the end of the experiments. On average, $\mathrm{H}_{2} \mathrm{~S}$ breakdown at $9.9 \pm 0.8$ minute in the seawater when dissolved oxygen is in excess. The $\mathrm{H}_{2} \mathrm{~S}$ breakdown reaction appears to be a first order reaction, when the dissolved oxygen is not a limiting factor.

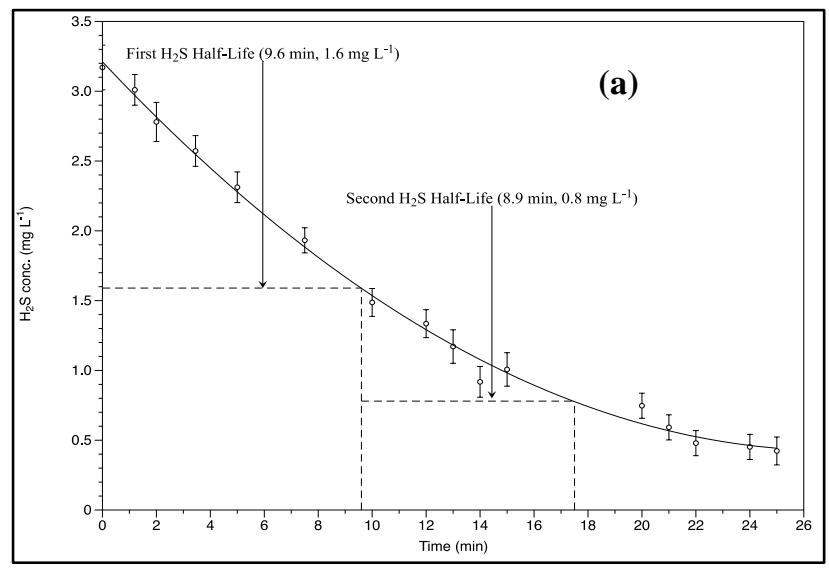




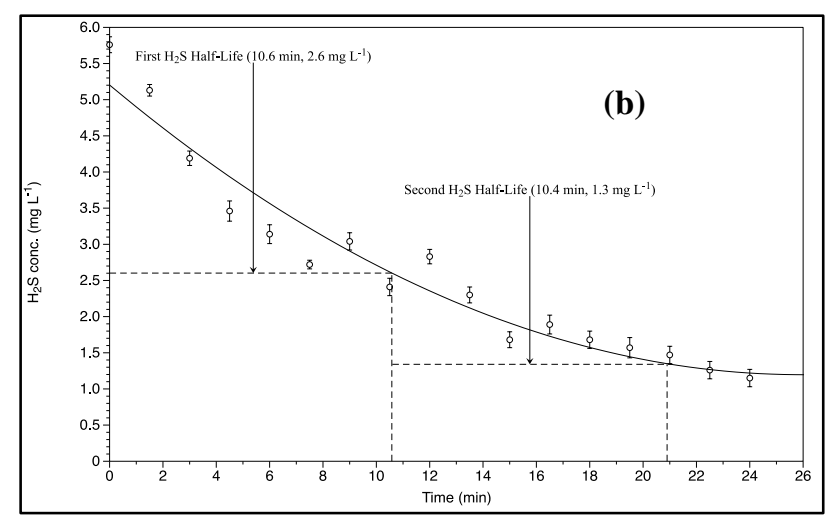

Figure 5. Hydrogen sulfide breakdown in the seawater at (a) initial dissolved oxygen of $10.2 \mathrm{mg} \mathrm{L}^{-1}$, [DO/ $\mathrm{H}_{2} \mathrm{~S}$ ] ratio 3.4 (b) initial dissolved oxygen of $17.4 \mathrm{mg} \mathrm{L}^{-1},\left[\mathrm{DO} / \mathrm{H}_{2} \mathrm{~S}\right]$ ratio 3.2

\section{Hydrogen sulfide breakdown in seawater at low $\left[\mathrm{DO} / \mathrm{H}_{2} \mathrm{~S}\right]$ molarity ratio}

Under low $\left[D O / \mathrm{H}_{2} \mathrm{~S}\right]$ molarity ratio, as the hydrogen sulfide $\left(\mathrm{H}_{2} \mathrm{~S}\right)$ is oxidized, the concentration of DO in the seawater decreased in tandem with the decrease in $\mathrm{H}_{2} \mathrm{~S}$ concentration. In this case, $\mathrm{H}_{2} \mathrm{~S}$ breakdown no longer resemble a first order reaction due to the dissolved oxygen depletion in the seawater. $\mathrm{Th}_{2} \mathrm{H}_{2} \mathrm{~S}$ breakdown is rather regulated by the availability of the dissolved oxygen. Figure 6 shows a typical $\mathrm{H}_{2} \mathrm{~S}$ concentration decline as it is reacted with DO under a low $\left[\mathrm{DO} / \mathrm{H}_{2} \mathrm{~S}\right]$ concentration ratio. The $\mathrm{H}_{2} \mathrm{~S}$ half-life at initial conditions of the experiment was estimated based on equation (4) provided earlier. Further experiments were conducted at low $\left[\mathrm{DO} / \mathrm{H}_{2} \mathrm{~S}\right]$ ratios to derive the correlations of $\mathrm{H}_{2} \mathrm{~S}$ breakdown in seawater and determine the approximate $\mathrm{H}_{2} \mathrm{~S}$ half-life under those conditions. The experiments were conducted such that the $\left[\mathrm{DO} / \mathrm{H}_{2} \mathrm{~S}\right]$ molarity ratio range spanned from less than 0.1 to above 10. This would provide adequate evidence of any correlation between the concentration ratio and the dissociation half-life. Table 3 below provides the measured $\mathrm{H}_{2} \mathrm{~S}$ half-life for various [DO/ $\left.\mathrm{H}_{2} \mathrm{~S}\right]$ ratio.

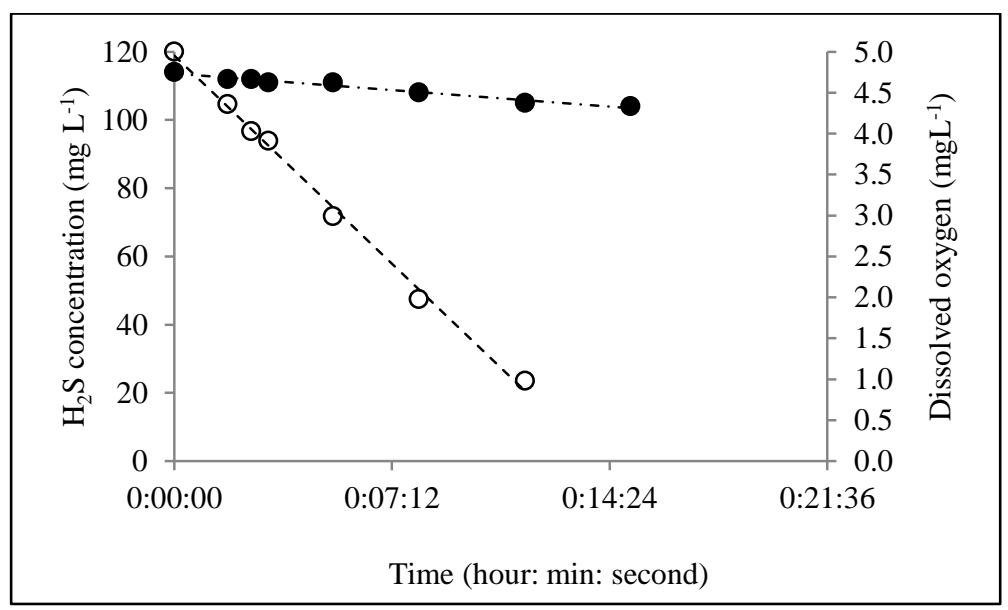

Figure 6. Typical hydrogen sulfide breakdown in seawater at low $\left[\mathrm{DO} / \mathrm{H}_{2} \mathrm{~S}\right]$ concentration ratio $\left[\mathrm{H}_{2} \mathrm{~S}\right.$ initial concentration $=114 \mathrm{mg} \mathrm{L}^{-1} ; \mathrm{DO}$ initial concentration $\left.=5 \mathrm{mg} \mathrm{L}^{-1}\right]$. Open blank circle indicates dissolved oxygen while filled circle indicates concentration of hydrogen sulfide in seawater 
Table 3. $\mathrm{H}_{2} \mathrm{~S}$ Half-life at various $\left[\mathrm{DO} / \mathrm{H}_{2} \mathrm{~S}\right]$ ratio

\begin{tabular}{|c|c|c|c|}
\hline$\left[\mathrm{DO} / \mathrm{H}_{2} \mathrm{~S}\right]$ Ratio & $\begin{array}{c}\mathrm{H}_{2} \mathrm{~S} \text { Initial Conc. } \\
\left(\mathrm{mg} \mathrm{L}^{-1}\right)\end{array}$ & $\begin{array}{l}\text { DO Initial Conc. } \\
\left(\mathrm{mg} \mathrm{L}^{-1}\right)\end{array}$ & $\begin{array}{c}\mathrm{H}_{2} \mathrm{~S} \text { Half-life } \\
(\mathrm{min})\end{array}$ \\
\hline 0.05 & 114.0 & 5.0 & 82.1 \\
\hline 0.16 & 92.7 & 14.0 & 35.7 \\
\hline 0.49 & 43.2 & 20.0 & 17.3 \\
\hline 3.41 & 3.2 & 10.2 & 10.3 \\
\hline 12.02 & 1.5 & 16.4 & 3.3 \\
\hline
\end{tabular}

As can be seen from Table 3 and Figure 7 , the $\mathrm{H}_{2} \mathrm{~S}$ half-life versus $\left[\mathrm{DO} / \mathrm{H}_{2} \mathrm{~S}\right]$ concentration ratio reveal a non-linear regression. The $\log$ transformed half-life and $\left[\mathrm{DO} / \mathrm{H}_{2} \mathrm{~S}\right]$ ratio showed a significant regression $(\mathrm{P}<0.05, \mathrm{y}=-0.54 \mathrm{x}+$ $1.16, \mathrm{R}^{2}=0.9687$ ). Figure 7 shows the $\mathrm{H}_{2} \mathrm{~S}$ half-life plotted against the molarity ratio of $\left[D O / \mathrm{H}_{2} \mathrm{~S}\right]$ in a $\log -\log$ plot. The relationship between the $\left[\mathrm{DO} / \mathrm{H}_{2} \mathrm{~S}\right]$ versus $\mathrm{H}_{2} \mathrm{~S}$ half-life resembles an inverse relationship, where decomposition of $\mathrm{H}_{2} \mathrm{~S}$ is very much dependent on the presence of dissolved oxygen in the seawater. Based on Figure 7, when $\left[D O / \mathrm{H}_{2} \mathrm{~S}\right]$ concentration ratio is lower than 0.07 , the $\mathrm{H}_{2} \mathrm{~S}$ half-life will extend beyond hour. When the $\left[\mathrm{DO} / \mathrm{H}_{2} \mathrm{~S}\right]$ ratio is higher than 1.1, the $\mathrm{H}_{2} \mathrm{~S}$ half-life will fall within 10 minutes.

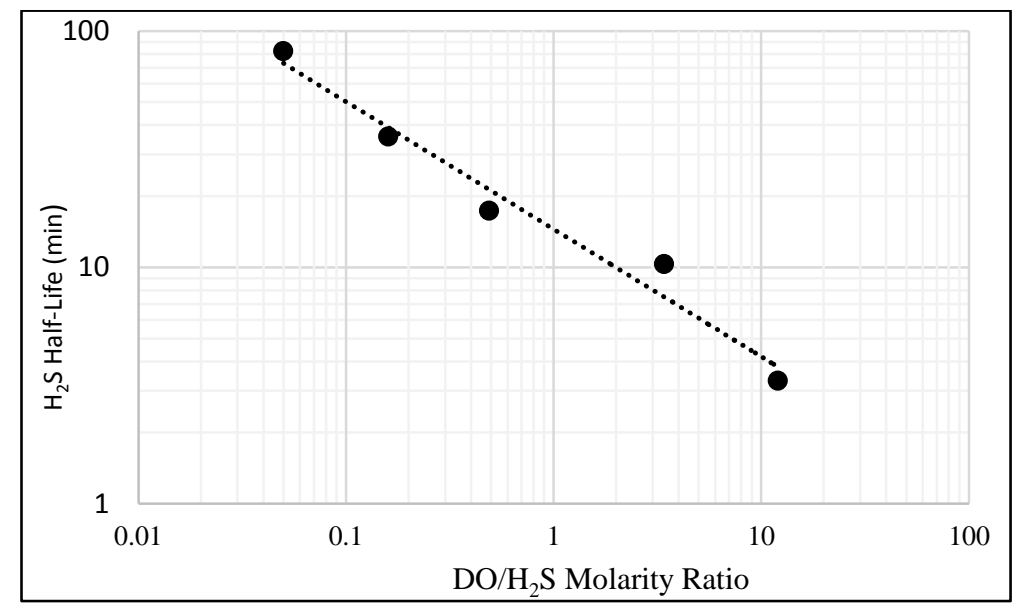

Figure 7. Hydrogen sulfide half-life versus the molarity ratio of $\left[\mathrm{DO} / \mathrm{H}_{2} \mathrm{~S}\right]$ in a $\log$-log plot

Table 4 shows a compilation of $\mathrm{H}_{2} \mathrm{~S}$ half-life reported in various reports. The $\mathrm{H}_{2} \mathrm{~S}$ half-life reported ranged from 17 minutes up to 55 days. Our current finding is consistent with the previous reports which reported that oxidation of $\mathrm{H}_{2} \mathrm{~S}$ resembles a first order reaction in seawater when the dissolved oxygen is high and unlimited and becomes a second order reaction when dissolved oxygen is depleting [7, 8]. Nevertheless, both group of researchers reported that oxidation of $\mathrm{H}_{2} \mathrm{~S}$ in seawater involved a series of complicated processes that are dependent on the composition and conditions of seawater. Different seawater conditions; which include physical, chemical and biological parameters is interacting and will influent $\mathrm{H}_{2} \mathrm{~S}$ breakdown in the seawater.

Pos et al. [18] reported $\mathrm{H}_{2} \mathrm{~S}$ in seawater subjects to photo-oxidation that had a half-life of $45 \pm 15$ minutes in Biscayne Bay water and $147 \pm 15$ minutes in the Gulf stream while Heitmann and Blodau [19] reported oxidation and incorporation of $\mathrm{H}_{2} \mathrm{~S}$ by dissolved organic matter in seawater. Luther et al. [20] reported a complicated inorganic and biological mediated processes in the fate of $\mathrm{H}_{2} \mathrm{~S}$ in the seawater environment. To the best of our survey, we have not encounter any comprehensive report that reveals the total interaction of physical, chemical and 
Hii et al: BREAKDOWN OF HYDROGEN SULFIDE IN SEAWATER UNDER DIFFERENT RATIO OF

DISSOLVED OXYGEN/ HYDROGEN SULFIDE

biological factors into the $\mathrm{H}_{2} \mathrm{~S}$ breakdown in seawater and the complicated interaction is probably the reasons that lead to various $\mathrm{H}_{2} \mathrm{~S}$ half-life reported in the seawater.

Table 4. $\mathrm{H}_{2} \mathrm{~S}$ breakdown half-life reported in seawater

\begin{tabular}{|c|c|c|c|}
\hline Medium & Experimental Conditions & Half-Life & References \\
\hline Seawater & $\begin{array}{l}\text { Temperature }=28^{\circ} \mathrm{C} \\
\text { Salinity }=30 \mathrm{ppt} \\
\text { Hydrogen sulfide }=1.5-114 \mathrm{mg} \mathrm{L}^{-1} \\
\text { DO }=5-16.4 \mathrm{mg} \mathrm{L}^{-1}\end{array}$ & $3.3-82.1 \mathrm{~min}$ & Present study \\
\hline Seawater & $\begin{array}{l}\text { Temperature }=9.8^{\circ} \mathrm{C} \\
\text { Salinity }=30.27 \mathrm{ppt} \\
\text { Total sulfide }=2.0 \mathrm{mg} \mathrm{L}^{-1} \\
\text { DO = DO: Total sulfide ratio from } 8-2 \\
\mathrm{pH}=9.6\end{array}$ & $6-28 \mathrm{~h}$ & [7] \\
\hline Seawater & $\begin{array}{l}\text { Temperature }=25^{\circ} \mathrm{C} \\
\text { Salinity }=35 \mathrm{ppt} \\
\mathrm{H}_{2} \mathrm{~S}=0.85 \mathrm{mg} \mathrm{L}^{-1} \\
\mathrm{pH}=8.0\end{array}$ & $26 \mathrm{~h}$ & [8] \\
\hline Seawater & $\begin{array}{l}\text { Temperature }=25^{\circ} \mathrm{C} \\
\text { Salinity }=\text { Not reported } \\
\mathrm{H}_{2} \mathrm{~S}=\text { Not reported } \\
\mathrm{DO}=3.8 \mathrm{ml} / \mathrm{l} \\
\mathrm{pH}=\text { Not reported }\end{array}$ & $17 \mathrm{~min}$ & [10] \\
\hline Seawater & $\begin{array}{l}\text { Temperature }=\text { Not reported } \\
\text { Salinity }=30 \mathrm{ppt} \\
\mathrm{H}_{2} \mathrm{~S}=20 \mathrm{mg} \mathrm{L}^{-1} \\
\mathrm{DO}=\text { Not reported } \\
\text { pH = Not reported }\end{array}$ & $45 \mathrm{~min}$ & [11] \\
\hline $\mathrm{NaCl}$ solution & $\begin{array}{l}\text { Temperature }=25^{\circ} \mathrm{C} \\
\text { Salinity }=\text { Not reported } \\
\mathrm{H}_{2} \mathrm{~S}=\text { Not specified } \\
\mathrm{DO}=\text { Saturation } \\
\mathrm{pH}=12\end{array}$ & 55 day & [20] \\
\hline Artificial seawater & $\begin{array}{l}\text { Temperature }=\text { Not reported } \\
\text { Salinity }=16.5 \mathrm{ppt} \\
\mathrm{H}_{2} \mathrm{~S}=25 \mathrm{mg} \mathrm{L} \\
\mathrm{DO}=\text { Not reported } \\
\text { pH = Not reported }\end{array}$ & $57 \mathrm{~min}$ & [21] \\
\hline Seawater & Not reported & $2-5 \mathrm{~h}$ & [22] \\
\hline Seawater & $\begin{array}{l}\text { Temperature }=\text { Not reported } \\
\text { Salinity }=\text { Not reported } \\
\mathrm{H}_{2} \mathrm{~S}=513 \mu \mathrm{g} \mathrm{L}^{-1} \\
\mathrm{DO}=\text { Not reported } \\
\mathrm{pH}=9.6\end{array}$ & $30 \mathrm{~min}$ & [23] \\
\hline
\end{tabular}




\section{Conclusion}

Hydrogen sulfide $\left(\mathrm{H}_{2} \mathrm{~S}\right)$ breakdown in seawater is highly dependent on the concentration of dissolved $\mathrm{H}_{2} \mathrm{~S}$ and the concentration of dissolved oxygen (DO). The rate of $\mathrm{H}_{2} \mathrm{~S}$ breakdown can be generally estimated based on the molarity ratio of $\left[\mathrm{DO} / \mathrm{H}_{2} \mathrm{~S}\right]$. At high $\left[\mathrm{DO} / \mathrm{H}_{2} \mathrm{~S}\right]$ ratio (> 1), the $\mathrm{H}_{2} \mathrm{~S}$ breakdown rate can be rapid, resulting in short half-life of $\mathrm{H}_{2} \mathrm{~S}$ dissociation (within 10 minutes). Under this circumstance where the dissolved oxygen is not a limiting factor in the $\mathrm{H}_{2} \mathrm{~S}$ oxidation, the breakdown rate appears as a first order reaction. However, when the ratio of $\left[\mathrm{DO} / \mathrm{H}_{2} \mathrm{~S}\right]$ ratio is lower than 0.07 , the breakdown rate became slower, resulting in longer half-life of $\mathrm{H}_{2} \mathrm{~S}$ breakdown (more than an hour's). In this case, the breakdown rate displays a second order reaction form, which concurred with reports from other investigators. This study also investigated relation between the dissolved $\mathrm{H}_{2} \mathrm{~S}$ content and $\mathrm{pH}$ changes in the seawater. The $\mathrm{pH}$ of seawater became lowered with increasing initial $\mathrm{H}_{2} \mathrm{~S}$ concentration in the seawater. It reached an asymptotic low value of about 4 as the dissolved $\mathrm{H}_{2} \mathrm{~S}$ content approaches its saturation limit in the seawater at about $2,500 \mathrm{mg} \mathrm{L}^{-1}$.

\section{Acknowledgement}

The authors would like to thank Sapura Kencana Energy Inc. for supporting the study.

\section{References}

1. Karl, D. M. (1995). The microbiology of deep sea thermal vents. CRC Press, New York, pp. 299.

2. Ellis, A. J. and Golding, R. M. (1959). Spectrophotometric determination of the acid dissociation constants of hydrogen sulphide. Journal of the Chemical Society, 1959: 127 - 130.

3. Savenko, V. S. (1977). The dissociation of hydrogen sulfide in seawater. Oceanology, 16: 347 - 350.

4. Barbero, J. A., McCurdy, K. G. and Tremaine, P. R. (1982). Apparent molal heat capacities and volumes of aqueous hydrogen sulfide and sodium hydrogen sulfide near $25^{\circ} \mathrm{C}$ : The temperature dependence of $\mathrm{H}_{2} \mathrm{~S}$ ionization. Canadian Journal of Chemistry, 60(14): 1872 - 1880.

5. Millero, F. J., Plese, T. and Fernandez, M. (1988). The dissociation of hydrogen sulfide in seawater. Limnology and Oceanography, 33(2): $269-274$.

6. Zavodnov, S. S., and Kryukov, P. A. (1960). The value of the second dissociation constant of hydrogen sulfide. Bulletin of the Academy of Sciences of the USSR, Division of Chemical Science, 9(9): 1583 -1585.

7. Cline, I. D. and Richards, F. A. (1969). Oxygenation of hydrogen sulfide in seawater at constant salinity, temperature and pH. Environmental Science and Technology, 3(9): 838 - 843.

8. Millero, F. J., Hubinger, S., Fernandez, M. and Garnett, S. (1987). Oxidation of $\mathrm{H}_{2} \mathrm{~S}$ in seawater as a function of temperature, pH, and ionic strength. Environmental Science and Technology, 21(5): $439-443$.

9. Chen, K. Y. and J. C. Morris. (1972). Kinetics of oxidation of aqueous sulphide by $\mathrm{O}_{2}$. Environmental Science and Technology, 6(6): $529-537$.

10. Göte, H. Ö. and Alexander, J. (1963). Oxidation rate of sulfide in seawater, a preliminary study. Journal of Geophysical Research, 68(13): 3995 - 3997.

11. Sharma, K. R. and Yuan, Z. (2010). Kinetics of chemical sulfide oxidation under high dissolved oxygen levels. Proceedings of $6^{\text {th }}$ International Conference of Sewer Processes and Networks: $1-3$.

12. Asaoka S., Yamamoto, T., Takahashi, Y., Yamamoto, H., Kim, K. H. and Orimoto, K. (2012). Development of an on-site simplified determination method for hydrogen sulfide in marine sediment pore water using a shipboard ion electrode with consideration of hydrogen sulfide oxidation rate. Interdisciplinary Studies on Environmental Chemistry - Environmental Pollution and Ecotoxicology, 6: 345 - 352.

13. Baumgartner, L. K., Reid, R. P., Dupraz, C., Decho, A. W., Buckley, D. H., Spear, J. R., Przekop, K. M. and Visscher, P. T. (2006). Sulfate reducing bacteria in microbial mats: changing paradigms, new discoveries. Sedimentary Geology, 185: $131-145$.

14. Poulton, S. W., Krom, M. D., Raiswell, R. and Raiswell, R. (2004). A revised scheme for the reactivity of iron (oxyhydr)oxide minerals towards dissolved sulfide. Geochimica et Cosmochimica Acta, 68: 3703 - 3715.

15. Yao, W., and Millero, F. J. (1996). Oxidation of hydrogen sulfide by hydrous Fe(III) oxides in seawater. Marine Chemistry, 52: 1 - 16.

16. American Public Health Association (2005). Standard methods for examination of water and wastewater, American Public Health Association, W.W.A, Washington, D.C. 
17. Han, K., Chu, T., Hirst, J., Smith, I. W. M., Canneaux, S., Kim, Y., Calvo, F., de la Lande, A. Skodje, R. T., Kawai, S., Petters, B., Kapral, R., Kim, H. J., Zhao, Y., Yan, Y., Zhang J., Swiatla-Wojcik, D., Bertrand, P., Varandas, A. J. S., Borgis, D., Senthilkumar, K., Hase, W. L. and Gao, J. (2013). Reaction rate constant computations: Theories and applications. Royal Society of Chemistry, London pp. 572.

18. Pos, W. H., Milne, P. J., Riemer, D. D. and Zika, R. G. (1997), Photoinduced oxidation of $\mathrm{H}_{2} \mathrm{~S}$ species: A sink for sulfide in seawater, Journal of Geophysical Research, 102(11): 12831 - 12837.

19. Heitmann, T., and Blodau, C. (2006). Oxidation and incorporation of hydrogen sulfide by dissolved organic matter. Chemical Geology, 235(1): 12 - 20.

20. Luther, G. W., Findlay, A. J., MacDonald, D. J., Owings, S. M., Hanson, T. E., Beinart, R. A., and Girguis, P. R. (2011). Thermodynamics and kinetics of sulfide oxidation by oxygen: A look at inorganically controlled reactions and biologically mediated processes in the environment. Frontiers in Microbiology, 2(62): 1 - 9.

21. Dermendzhieva N., Razkazova-Velkova E., Martinov M., Ljutzkanov L. and Beschkov V. (2013). Oxidation of sulfide ions in model solutions of seawater using of metal catalysts built in carbon matrix. Journal of Chemical Technology and Metallurgy, 48(5): 465 - 468.

22. Almgren T., Dyrssen D., Elgquist B. and Johansson H. (1976). Dissociation of hydrogen sulfide in seawater and comparison of $\mathrm{pH}$ scale. Marine chemistry, 4: 289 - 297.

23. Aumond V., Waeles M., Salaün P., Gibbon-Walsh K., van den Berg C. M. G., Sarradin P. and Riso R. D. (2012). Sulfide determination in hydrothermal seawater samples using a vibrating gold micro-wire electrode in conjunction with stripping chronopotentiometry. Analytica Chimica Acta, 753: 42 - 47. 